\title{
A SOLDIER'S STATE? VETERANS AND THE WELFARE REGIME IN CROATIA
}

\author{
Danijela Dolenec \\ Faculty of Political Science \\ University of Zagreb \\ E-mail: danijela.dolenec@fpzg.hr
}

\author{
DOI: $10.20901 / \mathrm{an} .14 .03$ \\ Research note \\ Accepted: March 2018
}

\begin{abstract}
The paper theorizes about the type of welfare state that emerged in Croatia post-1990, focusing specifically on ways in which the evolution of welfare programmes for veterans, and the gradual strengthening of veteran organizations as pivotal political actors, impacted its morphology. Croatia currently has a population of around 500,000 registered veterans, which in the mid-1990 started organizing into powerful organizations. Partly in response to this mobilization, from 1994 onwards HDZ governments created a comprehensive institutional architecture of entitlements for veterans, instituting durable material linkages alongside symbolic ties to this population. The prominence of veterans as a pivotal political actor has impacted the development of the welfare regime in Croatia. Strong reliance on the family for a broad range of care work is the central feature Croatia shares with other conservative welfare regimes, while the clientelist character of state-society relations relates it specifically to their Southern variant. Distinctly, the "compensatory" character of welfare programmes, which is characteristic of veteran programmes, and of family policy in Croatia generally, creates contradictory impulses. What seems to have emerged is a specific clientelist variant of a conservative welfare regime, sustained by veteran mobilizations, while at the same time eroded by the dependency, resentment and a myriad of other social impacts of these programmes. Future research on the welfare state in Croatia will hopefully further explore the arguments that this paper brings forward.
\end{abstract}

Key words welfare state regimes, Esping Andersen, veterans, political mobilization, Croatia

\section{Introduction ${ }^{1}$}

In 2013, at the unveiling of Franjo Tuđman's statue in Split, Ćiro Blažević, the legendary soccer coach who was the late president's intimate friend, emotionally claimed that "we Croats are the

\footnotetext{
I would like to thank the three anonymous reviewers for their very helpful comments, which significantly impacted the final formulations in the paper. Any remaining weaknesses are of course my own.
}

most glorious warriors". ${ }^{2}$ Croatia is a society in which the question "where were you in 1991?" embodies the essence of political identity, distinguishing those who stood to fight against everybody else. This catchphrase is a rhetorical weapon used to silence those who dare

\footnotetext{
2 As reported in 24 sata, on May 17, 2013. Available at: https://www.24sata.hr/news/ ciro-mi-hrvati-smo-najveci-ratnici-da-senetko-ne-bi-zaje-315335. Accessed February $22,2018$.
} 
question the official narrative that glorifies the Homeland War. The soldier is the ideal citizen, and the veteran deserves special rights for making the state (Jović 2017). Such a militarized political culture is probably sustained by more than the collective memory of the war. Salient political identities emerge from successful political mobilization that shapes dominant political cleavages and influences the state's distributive decisions. Attempting to shed some light on this complex dynamic, this paper focuses in particular on the evolution of welfare programmes for veterans and how they play into the type of welfare regime that has emerged in Croatia.

Thirty years has gone by since Esping Andersen (1990) typologized European welfare state regimes, describing their liberal, conservative and social democratic variants. Much ink has been spilled since in expanding, tweaking and criticising his typology, but its underlying analytical clarity is arguably still indispensable when attempting to abstract from thick descriptions of social programmes in a given national context, to something that would resemble a comparative analysis. This is true even if we are interested in the post-socialist region, where welfare systems arguably never fully conformed to any of Esping Anderson's three ideal types. Perhaps surprisingly, scholarship on post-socialist welfare regimes suggests that both their state socialist institutional legacies, and their post-1990 trajectories have made them resemble the conservative welfare regime type.

Taking all this on board, this paper attempts a tentative theorization of the type of welfare state that has emerged in Croatia, focusing specifically on ways in which social programmes for veterans ${ }^{3}$ impacted the morphology of the post1990 welfare state in Croatia. I aim to show that the development of comprehensive social programmes for veterans has contributed to a strengthening of an already conservative welfare regime. The paper first presents the major features of Esping Andersen's typology, and analyses features of post-socialist welfare regimes. After that it describes the evolution of legislating veterans' and their families' rights and entitlements, and provides estimates of the comparative breadth and comprehensiveness of welfare state programmes for veterans. The third section analyses the emergence and character of veterans' organizations, discussing their relevance as a civil society actor, while the fourth section looks at ways in which their political mobilization influences political dynamics in Croatia. In the conclusion I relate the described 'soldier's state' to Esping Andersen's typology, arguing that Croatia is best understood as a clientelist, conservative welfare regime with a myriad of contradictory social impulses.

\section{Welfare regimes in Europe, Post-Socialist Hybrids and Croatia}

The ideas that brought to life the $20^{\text {th }}$ century welfare state are now relics of the past, since the broad political consensus that brought it to life has long crumbled (Berman 2006; Thomson 2000; Keman 2017). Nevertheless, since institutions are generally sticky (Pierson 2004), and institutions that confer material benefits to citizens are particularly so, even after 30 years of convergence pressure under neoliberal policy recipes, one can still discern differences between social democratic, conservative and liberal welfare regimes. The underlying idea that redistributive social programmes should, in

self-identifies with, and is referred to, as "defenders" (branitelji, in Croatian).
I use the term veteran since this is how the population is referred to in the relevant literature, but in Croatia this population 
the final instance, fundamentally transform capitalist societies by emancipating citizens from economic necessity may have been marginalized, but the underlying rationale for the existence of a welfare state is still there: social programmes decommodify the individual vis-à-vis the market. Acknowledging that humans are not a commodity in the same way as cars are, welfare state programmes aim to reduce the dependence of human conditions of survival upon laws of demand and supply in the labour market (Esping Andersen 1990). Humans, apart from working, are expected to reproduce themselves and the societies in which they live in. This means that full human commodification, in which whether you live or die depends on you receiving a wage, is unsustainable - even from the point of view of the owners of capital (Esping Anderson 1990). At the same time, though a comprehensive welfare state became a common goal for postwar Western European societies, not all of them have accomplished the same level of decommodification of their populations, either in terms of level of social support, or its reach.

Developing these assumptions, Esping Andersen (1990), described types of cross-class coalitions that led to the development of three basic types of welfare state: liberal, conservative and social democratic. According to his understanding, differences among them were not simply 'more or less' in terms of social expenditure; there was also a qualitative difference, resulting from underlying political ideologies (Emmenegger et al 2015). The cornerstone institution tasked with the provision for human wellbeing in the liberal regime is the market, in the conservative it is the family, and in the social democratic regime it is the state. In other words, only social democratic welfare regimes strive to de-couple human wellbeing both from market forces and from family circumstances. And indeed, most recent analyses suggest that only social democratic regimes manage to enhance upward mobility chances for working class children (Esping Andersen 2015).

In contrast, liberal welfare regimes view "servicing as a natural market activity" (Esping Andersen 2000: 73), with social guarantees typically restricted to those worst off. Finally, in the conservative welfare regime, the family remains the primary source of social reproduction and social programmes are to a substantial extent tied to work status. This means that both liberal and conservative welfare regimes reinforce social stratitfication; in the liberal regime the key social stratification happens according to class, while "the essence of a conservative regime lies in its blend of status segmentation ${ }^{4}$ and familialism" (Esping Andersen 2000: 81). Familialism, a concept that captures both the male bread-winner bias of social protection and the centrality of the family as care-giver, is particularly relevant for conservative regimes in Southern Europe (Esping Andersen 2000). Subsequent literature, which aimed to address Esping Andersen's lack of attention to the ways in which gender structures welfare provision, further developed this concept. Leitner (2003: 357) argues that some welfare regimes are explicitly familialist, in that they not only "strengthen the family in caring for children, the handicapped and the el-

\footnotetext{
Esping Andersen refers to status segmentation also as corporativism. He measures corporativism as the number of occupationally distinct public pension schemes (1990, 2000). In Italy for instance pensions are divided into more than 120 occupational plans. In Germany on the other hand, there is modest corporativism in pensions, but the health insurance is 'a labyrinth of 1,200 separate regional, occupational, or company-based funds' (Esping Andersen 2000: 82).
} 
derly through familialistic policies", but they lack the provision of alternatives to family care. Welfare states vary in the extent to which governments reinforce patriarchal relations or aim to transform gender relations; on that continuum, explicit familialism is particularly conservative, reinforcing gendered parenting (Javornik 2014).

How were state socialist welfare systems different from the types just described? Orenstein (2008) highlights four significant differences. Firstly, state socialism was premised on the idea of full employment, ${ }^{5}$ and this meant that the tax base was wider, with less demand for state social assistance. ${ }^{6}$ Secondly, benefit levels and service quality were typically lower than in the West, but the extent and variety of social provision was broader. These systems provided universal medical care, old-age and disability pensions, maternity and family benefits - like Western states; but they also subsidized basic foodstuffs, provided housing, and made affordable cultural activities and vacation options. Thirdly, state owned enterprises took on important roles in social provision, providing housing, subsidized food, day care, vacation homes and so on. Finally, better services and housing were reserved for the privileged, while at the same time such provisions were available to a wide swath of the population. These governments aimed to provide widely for the working class, but at the same time used the welfare state as a mechanism for differential distribution, "to punish opponents and reward supporters" (Orenstein 2008: 83).

5 Yugoslavia is a partial exception, since it dealt with unemployment already within the socialist system (Milanović 1998).

6 Participation in the labour force, particularly among women, were higher than in liberal market economies where market incentives to work are very high (Orenstein 2008).
If we accept Orenstein's summary of welfare programmes in state socialist regimes, we can draw several inferences regarding their relationship to Esping Andersen's typology. Firstly, in terms of intention, the aim of these systems was universal welfare provision, with a dominant role played by the state - both as direct employer, ${ }^{7}$ and in the provision of services. Therefore, in intention, and partially in implementation, we could argue that they were closest to social democratic welfare regime types. At the same time, since Eastern European countries were much poorer, the actual level of benefits and the quality of services they provided was not at a comparable level to Scandinavian countries that embody the social democratic welfare regime. Taking this on board, and since in these systems the workplace was a key access point to social benefits (Deacon 2000: 147), suggest that socialist regimes resemble conservative welfare regimes. Furthermore, the fact that Communist parties typically manipulated state resources for patronage purposes is also more characteristic of conservative welfare regimes. For instance, Fererra (1996) described how in Italy, a conservative welfare regime in Esping Andersen's typology, disability pensions and public-sector jobs were the primary vehicles of political clientelism. ${ }^{8}$

\footnotetext{
In Yugoslavia in 1988 state employment as a proportion of the labour force was $78.9 \%$, compared to $21.2 \%$ OECD average (Milanović 1998).

8 While Ferrera (1996) argued that these, and some other features, warranted the introduction of a fourth, Southern welfare regime, Esping Andersen (2000) considered clientelism a "perverted use" of social programmes with important political implications, but not as a characteristic that would define a separate welfare regime. In Esping Andersen's typology, a "regime" refers to "the ways in which welfare production is allocated between state, market and households" (2000: 73). Much of the scholarship that aims to include new regions of the
} 
Deacon (2000) argues that the logic of post-socialist welfare regime trajectory was towards the conservative regime because workplace entitlements and status differentials could be easily converted into "insurance-based, wage related and differentiated benefit entitlements of the Austro-German, Bismarckian kind" (2000: 151-152). At the same time, this "natural" trajectory towards the conservative welfare regime was pushed towards the liberal type by budgetary pressures on governments during the economic transformation and aided by loan conditions of the IMF and World Bank (Deacon 2000). The immediate shock of regime change brought the abrupt removal of wide ranging subsidies and the collapse of guaranteed full employment, creating massive unemployment and poverty (Orenstein 2008). In Croatia, the percentage decline in GDP between 1987 and 1996 was 47\%, a decline surpassed in the post-socialist region only by Bosnia and Herzegovina and Tajikistan (Milanović 1998). The World Bank (2001: x) study for Croatia recorded that inequality in Croatia was "far higher than generally observed in transition and market economies".

Initially international economic advisers were focused on market liberalization and privatization, with little to say about social policy reform beside developing unemployment insurance (Orenstein and Haas 2005). This changed in the mid-1990s, when international financial institutions gained strong influence in social reform, creating convergence pressure towards neoliberal policies (Ferge 1997). Between 1994 and 2004, eleven post socialist countries, including Croatia, partially privatized their pension systems along the lines proposed by the World Bank (Orenstein

world into the typology, as well as analyse ways in which gender affected welfare state outcomes, often does not focus on this central feature of Esping Andersen's typology. and Haas 2005; Orenstein 2008). Overall, Orenstein concludes that European post-socialist states drew on their conservative Bismarckian traditions, with a strong reliance on social insurance and status-preserving benefits where "the better off have a stronger safety net" and where traditional family structures are supported (2008: 92). Going back to the discussion of familialism as a characteristic of conservative regimes, Dobrotić and Vučković (2016) classify Croatia in the explicit familialism group, where the state reinforces existing patriarchal relationships by relying on the family as the main source of care provision (Leitner 2003).

These analyses suggest that the welfare regime in Croatia is dominantly conservative, supporting various status differentials as well as traditional, patriarchal gender roles. How does the development of comprehensive social programmes for veterans fit into this picture? Stubbs and Zrinščak (2009, $2011,2015)$ discuss the provision of social programmes for veterans in terms of clientelist relations, where clientelism refers to "a broad set of hegemonic political practices and strategies marked by particularistic modes of governance, exclusivist definitions of citizenship, and asymmetrical distribution and redistribution of resources" (Stubbs and Zrinščak 2015: 398). According to the authors, multiple social processes in Croatia seem to speak in evidence of clientelism: a very large number of beneficiaries, the fact that veterans have higher level benefits than other social groups, increases in the coverage of these benefits during pre-election periods, as well as a lack of procedures of monitoring and assessment which would most probably increase efficiency of the system (2015). These descriptions echo Ferrera (1996) account of similar mechanisms of political clientelism in Italy. 
What about the impact that domestic political dynamics have on the evolution of the welfare regime? The main argument of the power resource approach is that ruling parties have significant impact on social policy development (Korpi 1983; Esping Andersen 1990; Aidukaite 2009; Häusermann et al. 2013). Countries with strong left-wing parties, powerful labour unions and a significant working-class presence in the decision-making apparatus developed social democratic welfare regimes, while comparatively weaker working class political mobilization led to liberal and conservative welfare regimes. In post-socialist Europe after 1990 the Left collapsed; former communist parties rebranded themselves into social democrats, but they effectively embraced neoliberalism (Greskovits 1996). Workers were symbolically and materially dethroned from the political stage (Dolenec 2014). In other words, there was no Left force to press for the development of a welfare state on universalist principles. Instead, out of 28 years since Croatia's independence, 20 have been under the leadership of the conservative nationalist political party HDZ. Over time, the political dynamic between this political party and veteran organizations significantly influenced the development and the morphology of the welfare state in Croatia. The following sections, two, three and four, look at the evolution of this social dynamic in more detail.

\section{The Evolution of Welfare Programmes for Veterans}

Scholarship that explores links between war, state-building and the development of the welfare state is not prolific. According to one recent summary (Maddaloni 2014), the key relationship stems from the fact that after the war has ended, soldiers and other participants in the war effort become a potential risk for the state, given the "democratization of violence facilities" that war entails. The state historically managed this risk of political unrest by stimulating nationalism and, subsequently also political citizenship (Bendix 1964; Gellner and Breuilly 1983). In Germany during Bismarck, nationalist fervour was also accompanied with the expansion of social entitlements (Wolin 1987). Similarly, in the United States Skocpol (1995) traces the origin of the welfare state to the Civil War. One of the main factors that drove the US to legislate social protection was the need to solve the political problem caused by veterans and the disabled from the Civil War. In response, the government established a benefit programme for veterans that eventually accounted for 18 percent of all federal expenditure (Gal and Bar 2000).

The relationship between the state and veterans is premised on a "moral asymmetry" whereby veterans suffer the absolute sacrifice, which the state only relatively compensates via material benefits (Begić, Sanader and Žunec 2007). Historically states provide veterans, and especially disabled veterans, with generous pensions and a vast array of medical, rehabilitation and reintegration services (Gerber 2003). These benefits are conceived as rights, not "welfare", which is used pejoratively to reference public assistance provided to those considered "unworthy" (Gal and Bar 2000). In that sense, the standard conception of welfare as a means for the state to exercise power over its citizens (Pateman 1988; Wolin 1987) is not applicable in the case of veterans. "Worthiness" as a basis for social entitlements (Williamson, Skocpol and Coggin 2012) is always present in the dynamic between the state and welfare recipients. Target populations of social programmes are not neutral, either to the state, or to public opinion. Instead, they are socially construct- 
Table 1. Power and social constructions - types of target populations

\begin{tabular}{|c|c|c|c|}
\hline & & \multicolumn{2}{|c|}{ Constructions } \\
\hline & & Positive & Negative \\
\hline \multirow{2}{*}{ Power } & Strong & $\begin{array}{l}\text { Advantaged: the elderly, } \\
\text { business, veterans, scientists }\end{array}$ & $\begin{array}{l}\text { Contenders: the rich, big } \\
\text { unions, minorities, cultural } \\
\text { elites, moral majority }\end{array}$ \\
\hline & Weak & $\begin{array}{l}\text { Dependents: children, } \\
\text { mothers, disabled }\end{array}$ & $\begin{array}{l}\text { Deviants: criminals, drug } \\
\text { addicts, communists, flag } \\
\text { burners, gangs }\end{array}$ \\
\hline
\end{tabular}

Source: Schneider and Ingram 1993: 336

ed, with normative characterisations that portray them in positive or negative terms through symbols, metaphors and stories (Schneider and Ingram 1993). Schneider and Ingram (1993) proposed a typology of target populations based on two key characteristics: whether they are powerful (based on their mobilization capacity) and whether they are construed as positive or negative. Table 1 shows their typology and the social groups they categorise.

According to Schneider and Ingram (1993), veterans represent an advantaged target population, which is both strong and positively socially construed. The implication of this typology is that advantaged groups will receive more beneficial policy than is warranted either in terms of policy effectiveness or representativeness. Furthermore, "advantaged groups have the resources and capacity to shape their own constructions and to combat attempts that would portray them negatively" (Schneider and Ingram 1993: 337). Once social protection mechanisms for veterans are instituted, interest groups organize to defend them (Gal and Bar 2000; Brooks and Manza 2007; Maddaloni 2014), creating an ongoing dynamic with the state. If the veteran group is large enough, like was the case in the late 19th century US, and in Croatia in the 1990s, veteran or- ganizations can become pivotal political players, forging alliances with political parties and influencing election outcomes. ${ }^{9}$

In the case of the US, Skocpol (1995) argues that the Republican Party fostered rapid growth of the veteran organization Grand Army of the Republic (GAR). This organization achieved many legislative successes regarding pensions and other benefits, and, according to Skocpol (1995), became organizationally and ideologically central to the politics of late 19th ct. America. Similarly, Ainsworth (1995) argues that the GAR was a formidable electoral player, influencing the soldiers' vote to affect outcomes of presidential and congressional races. Ainsworth (1995) finds that the GAR, successfully lobbied legislators to support both the Arrears Act of 1879 and the Disability Pension Act of 1890. The case of Croatia, as this paper shows, exhibits some important parallels to this dynamic. However, many

9 Recent research argues that the same can be said of veterans in Bosnia and Herzegovina. Obradović (2017) argues that veterans in Bosnia and Herzegovina are well organised, their associations are financed by the government and they have become important pressure groups in the country's political system. On veterans in Bosnia and Herzegovina see also Bougarel (2006), Berdak (2015) and Hronesova (2016). 
dimensions of this phenomenon are under-researched, so this paper puts together an incomplete mosaic that merits further investigation. ${ }^{10}$

Croatia had experience with welfare programmes for veterans before the Homeland War. Partisans who fought in the Second World War in Croatia were awarded the status of veterans in socialist Yugoslavia, and many received state-insured pensions. ${ }^{11}$ Furthermore, militarism was deeply embedded in Yugoslav culture, forming an integral part of one of its grand narratives (Berdak 2015). Socialist Yugoslavia "derived a great deal of its legitimacy from a founding myth according to which the people, united within the national liberation front, fought against the forces of occupation" (Bougarel 2006: 480). After the war the Communist party recruited massively from among the partisans, and SUBNOR - the Union of Associations of Combatants of the Struggle for National Liberation, was one of the party's major mass membership organizations. SUBNOR played a significant role in the allocation of pensions, housing, scholarships and other benefits, and it also maintained representatives in many government bodies. Veterans "were rewarded symbolically through high social

10 Comparatively speaking, welfare state programmes for veterans are one of the least researched fields of social security ( $\mathrm{Gal}$ and Bar 2000). This is probably due in part to the fact that most Western European welfare states have not been involved in major military conflicts since World War Two. In addition, veteran benefits tend to be administered by separate bureaucracies, often in the purview of military establishment, which makes them less accessible.

11 In 2009, 64,000 participants in the Second World War (both partisans and soldiers of the Independent State of Croatia, NDH) were receiving state-subsidised pensions. Incidentally, that same year the number of Homeland Veteran pensions was also 64,500 (Bađun 2009). status and financially through privileged access to pensions, flats and positions of authority within the Communist party" (Berdak 2015: 50). In that sense, the post-1990 legislation of veteran benefits was able to rely on both symbolic and institutional legacies from Yugoslavia.

Croatia underwent large-scale mobilization for the war. Full numbers for the Armed Forces of the Republic of Croatia (AFRC) at the time of war are difficult to ascertain. According to Marijan (2008), at the end of 1991 and beginning of 1992, the AFRC had 200,000 people under arms. Other sources quote the figure of around 300,000 people in total under arms in Croatia during 1991-1992. During 1993 the AFRC was reduced to 52,000 people, while in 1995 it was again expanded to 200,000 (Žunec 1998; Begić, Sanader and Žunec 2007). Counting people who took part in the armed resistance proved contentious, but according to the Official Registry of Veterans, the number of veterans in 2012 was 503,112 . In other words, around 11.7 percent of the population of Croatia are veterans of the Homeland War. In comparison, the United States have 9,3 m veterans, amounting to around $2.9 \%$ of the population. According to Smeric (2009), the AFRC, formed during the Homeland War through mass participation, represent one of the formative institutions of contemporary Croatian state, impacting not only state-administrative structures, but the entire institutional configuration of Croatian society.

Homeland War veterans' rights were legislated from 1994 onwards. ${ }^{12}$ The state kept the registry of veterans secret for almost 20 years; it was only made public in 2012, under the government

\footnotetext{
12 In 1992 and 1994 the Croatian government added soldiers who fought on the side of the puppet Nazi regime in Croatia 1941-45 (NDH) to the status of veterans (Begić, Sanader and Žunec 2008).
} 
led by the Social Democrats (SDP). In 2013, the SDP government reported the number of veterans at 503,112. If this number is compared to the one reported for 2008 (Begić, Sanader and Žunec 2007), it seems that 13,700 people were added to the official registry between 2008 and 2012. Also, though open conflict started in mid-1991 and the last military operation took place in August 1995, subsequent legislation regulating veteran status extended the period of "armed resistance" from $\mathrm{Au}-$ gust 1990 until June 1996 (Begić, Sanader and Žunec 2007). Hence, one of the larger intakes of new personnel happened in 1996, a year after military operations had ended (Mahečić 2003). The report of the Parliamentary Committee of Veterans from October $2014^{13}$ stated that the number of veterans in the official registry keeps growing, despite the 2009 ban on new registrations. In other words, since getting listed in the official registry is a precondition for claiming a host of social entitlements, this status has become a much sought good.

HDZ governments started legislating veteran rights in 1994, with significant changes to the legislation in 1996, 2001 and 2004 (Begić, Sanader and Žunec 2007). By 2004, the law accorded 37 different material entitlements to this population, most importantly including pensions, disability compensation, paid heath and care services, priority in securing housing, child allowance, unemployment benefits, financial help in securing employment, tax cuts, scholarships, guaranteed university entry, and many others. A comparative study of

13 Information from the document "Izvješće Odbora za ratne veterane o provedbi Zakona o pravima hrvatskih branitelja iz Domovinskog rata i članova njihovih obitelji za 2013. dodinu". Available at http://www. sabor.hr/izvjesce-odbora-za-ratne-veterane-o-provedbi-z0001. Accessed February $25,2018$. eleven countries, including the US, Israel and Germany, found Croatia at the very top regarding the extent and quality of benefits accorded to veterans (Ferenčak, Kardov and Rodik 2003; Žunec 2006; Dobrotić 2008). The Act from 2004 was further amended in 2005, twice in 2007, twice in 2009, in 2010, 2011, 2012, three times in 2013, once in 2014 and an entirely new Act with significant increases in rights and material entitlements was introduced in 2017. The 2017 Act reopened the possibility to register as a war veteran, reduced the retirement age, extended the rights of family members to inherit veterans' pensions, introduced mandatory financing of veterans' associations, as well as a number of other social benefits (European Commission, 2018). Between its introduction in November 2017 and February 2018, 3,955 applications for the status of disabled war veteran have been registered with the Ministry of Veterans. ${ }^{14}$

According to the last available report published by the Croatian Government in $2013,{ }^{15}$ the total annual material compensation to veterans was 5,9 bn Kuna, which amounted to $5 \%$ of the state budget (VRH 2014) and around $1,8 \%$ of Croatia's GDP (HNB 2014). Veteran pensions represented the largest share of this budget, with over 5 bn Kuna in 2013. ${ }^{16}$ This was followed by "permanent material compensation"

14 Information published by Večernji list, available at: https://www.vecernji.hr/ vijesti/u-samo-dva-mjeseca-4000-branitelja-zatrazilo-status-ratnog-vojnog-invalida-1231339. Accessed March 16, 2918.

15 Publishing reports regarding the implementation costs of veteran related legislation were discontinued after HDZ returned to government in 2015 .

16 According to the Parliamentary Committee on Veterans, for 2016 the planned budget for veteran pensions was 4,1 bn Kuna. Available at http://www.sabor.hr/izvjesce-odbora-za-ratne-veterane-o-prijedlogu0010. Accessed on February 25, 2018. 
Table 2. Government expenditure on social protection as percentage of GDP, 2015

\begin{tabular}{lcccccc}
\hline & $\begin{array}{c}\text { Social } \\
\text { protection }\end{array}$ & $\begin{array}{c}\text { Sickness } \\
\text { and } \\
\text { disability }\end{array}$ & Old age & $\begin{array}{c}\text { Family and } \\
\text { children }\end{array}$ & $\begin{array}{c}\text { Unem- } \\
\text { ployment }\end{array}$ & Housing \\
\hline EU 28 & 19.2 & 2.8 & 10.3 & 1.7 & 1.4 & 0.5 \\
Croatia & 15.1 & 4.9 & 6.7 & 1.3 & 0.5 & 0.0 \\
Slovenia & 17.4 & 2.3 & 9.9 & 2.0 & 0.6 & 0.0 \\
\hline
\end{tabular}

Table 3. Government expenditure on social protection as percentage of total expenditure, 2015

\begin{tabular}{lcccccc}
\hline & $\begin{array}{c}\text { Social } \\
\text { protection }\end{array}$ & $\begin{array}{c}\text { Sickness } \\
\text { and } \\
\text { disability }\end{array}$ & Old age & $\begin{array}{c}\text { Family and } \\
\text { children }\end{array}$ & $\begin{array}{c}\text { Unem- } \\
\text { ployment }\end{array}$ & Housing \\
\hline EU 28 & 40.6 & 5.9 & 21.7 & 3.7 & 2.9 & 1.2 \\
Croatia & 32.3 & 10.5 & 14.2 & 2.8 & 1.0 & 0.0 \\
Slovenia & 36.4 & 4.7 & 20.7 & 4.1 & 1.3 & 0.0 \\
\hline
\end{tabular}

Source: Eurostat 2017.

amounting to 696,6 million Kuna, a category administered by the Ministry of Veterans, pertaining to disability compensation and other forms of social compensation distributed via a complex web of regulations. Of the total number of veterans, in September 2016, 72,001 were recipients of state pensions, 57,173 (approx. 80\%) of which receive disability pensions (Croatian Pension Fund 3/2016). ${ }^{17}$ This amounts to 1.3 per cent of the population - compared to 0.85 per cent of the overall population of Israel and 0.9 per cent of the overall population of the US (Gal and Bar 2000). In addition to its wide reach, the pension programme for disabled veterans in Croatia is generous. Veter-

17 Bosnia and Herzegovina has also developed a very substantial welfare state programme for veterans. According to some sources, nearly 100,000 veterans in Bosnia and Herzegovina receive disability pensions (Popić and Panjeta 2010). an pensions are 2.7 to 3.1 times higher than standard pensions, while veteran disability pensions are around 3 times higher than general disability pensions (Bađun 2009). ${ }^{18}$ Similarly, in the category of family pensions, veteran family pensions are 4 times higher than general family pensions. With reference to income levels, the average pension in Croatia is around $40 \%$ of average net salary, while average veteran pensions are higher than the average net salary (Bađun 2009). In comparison, in Israel, a welfare state with comprehensive provisions for veterans, fully disabled veterans receive benefits at the level of $66 \%$ of the average wage (Gal and Bar 2000).

18 This large difference was noted also by the European Commission (2018), quoting data from September 2017 from the Croatian Pension Insurance Institute, that general pensions for war veterans tend to be more than twice as high compared to the general scheme. 
How do these veteran benefits fit into the broader picture of welfare programmes provided by the Croatian state? According to the 2010 World Bank report on Croatia, social assistance in Croatia heavily relies on "categorical" as opposed to needs-based benefits. ${ }^{19}$ The largest share of social assistance spending in Croatia goes to veterans and their survivors - amounting to $1.8 \%$ of GDP in 2009, compared to 0.5 percent of GDP that goes to poor families with children (World Bank 2010: 51). The only post-socialist country with a similar composition of social spending is Bosnia and Herzegovina, both in terms of overall size of social spending in proportion to GDP, and the dominance of social assistance to veterans in the composition of social spending. According to the World Bank (2010), the size of veteran benefits in proportion to Croatia's GDP has been growing steadily since 2004.

Tables 2 and 3 show 2015 data on government expenditure on social protection, first as percentage of GDP, and then as percentage of total expenditure. Croatia is compared with the EU 28 average, and with Slovenia, a country with which Croatia shared institutional features until the dissolution of Yugoslavia.

Croatia is below EU average regarding the level of social spending, both in terms of relationship to GDP, and as a percentage in the overall government expenditure. Denmark, Finland and France are among countries with the highest social spending of between 23-26\% of GDP (Eurostat 2017), compared to Croatia's $15 \%$. In other words, Croatia is far from a social democratic welfare regime in terms of the size of its welfare state. In terms of categories

19 Means tested programmes play only a marginal role in Croatia's welfare state programmes, accounting for only $7 \%$ of total spending (World Bank 2010). of social spending, Croatia is below EU average in all categories except for "sickness and disability". Though Eurostat's methodology does not allow us to compare levels of veteran benefits directly, it is plausible to expect that Croatia's "bloated" figure for sickness and disability is largely due to veteran disability pensions. Regarding levels of social expenditure on other categories, the contrast with Slovenia is instructive. While on a comparable level of overall expenditure on social protection, Slovenia has higher levels of expenditure than Croatia in all categories except sickness and disability. For instance, while in Croatia $2.8 \%$ of government expenditure goes towards family and children, it Slovenia the corresponding figure is $4.1 \%$ (and in Denmark it is $8.3 \%$ ). In its most recent report, the European Commission stated that regarding social protection of people below 65 years of age, Croatia is characterised by poor targeting of those most in need, while at the same time supporting "privileged categories such as war veterans" (2018: 22).

Though these figures may create the impression of a highly-privileged population, analysts note that compensatory government programmes have created a passive, state-dependent population (Dobrotić 2008). Given that during the war these were generally young people, most often with only secondary education qualifications, with little or no job experience prior to going to war, the compensatory approach has contributed to their social isolation (ibid.). In the 1990 s, veterans were overrepresented in lower socioeconomic groups such as the unemployed, welfare recipients and the poor (Žunec 2006). More recently, the European Commission (2018) reports how little progress has been made to support war veterans' re-integration into the labour market. 
This "compensatory" approach towards the veteran population echoes findings regarding the similarly "compensatory" character of family policy in Croatia (Zrinščak 2008; Dobrotić 2015). Croatia is characterised by one of the lowest coverage rates of children in pre-school education and care (Matković and Dobrotić 2013), which contributes to mothers leaving the labour market, and to their generally lower employment rates (Dobrotić 2015). In that sense it could be argued that the state's programmes for veterans have been incorporated within the framework of explicit familialism (Vučković and Dobrotić 2016) and state paternalism both of which are features of conservative welfare regimes (Esping Andersen 2000). However, because veterans are, according to Schneider and Ingram (1993) "advantaged" groups, while children and mother are "dependents", this results in over-allocating resources to the first group, while mostly paying lip service to the other. As Schneider and Ingram (1993: 338) argue, the state wants to appear aligned with the interests of children and mothers, "but their lack of political power makes it difficult to direct resources toward them". In other words, the veterans' capacity for political mobilization represents the crucial distinction of this population, which is analysed in the following two sections.

\section{Veterans as a Civil Society Actor}

Though HDZ governments in the early 1990s were willing to provide material compensation to the veteran population, arguably much of the generous package would not have happened without veterans organizing and putting pressure on the state. In the spring of 1992 the first veteran NGO was founded, and in 1993 they held a federative assembly of over 15 chapters. The assembly meeting was attended by the
President of Croatia, Franjo Tuđman, and General Martin Špegelj, the first Chief of Staff of the Croatian Armed Forces, was elected president of the association.

The Association of Patriotic War Volunteers and Veterans of the Republic of Croatia (UDVDR), as the federation is called, today has 21-member organizations at county level, over 200 chapters on the local level, and around 80 social clubs. Its website boasts a membership of 220,000, "representing the population of around 350,000 Croatian veterans, who together with their families come close to one million citizens of Croatia". ${ }^{20}$ The Association of Disabled Veterans of the Homeland War (HVIDR-a) is similarly federated across Croatia, with member organizations on the county level. ${ }^{21}$ According to Mihalec, Pavlin and Relja (2012), HVIDRa has a membership of 35,000 , with 20 regional and 105 local chapters. Its president served as HDZ's Member of Parliament and he headed the parliamentary Board for Veterans. ${ }^{22}$ During 2010, veteran NGOs participated in 13 advisory and consultative bodies of the government, spanning issues from employment policies to regional development. According to Lendvai and Stubbs (2015: 460), HVIDRa enables veterans "to play a strong political role in Croatia and are addressed as a key beneficiary of extensive social benefits, much higher than those received by civilian victims of war or by those at risk of poverty and social exclusion". Finally,

20 Quoted from the website of the organization, accessible in Croatian at http://www. udvdr.hr/povjesnica-2/. Accessed on February 25, 2018.

21 The website of HVIDR-a is much less informative about its size and composition; http://www.hvidra.hr/

${ }^{22}$ HVIDRA also plays an important political role in Bosnia and Herzegovina (Berdak 2015). 


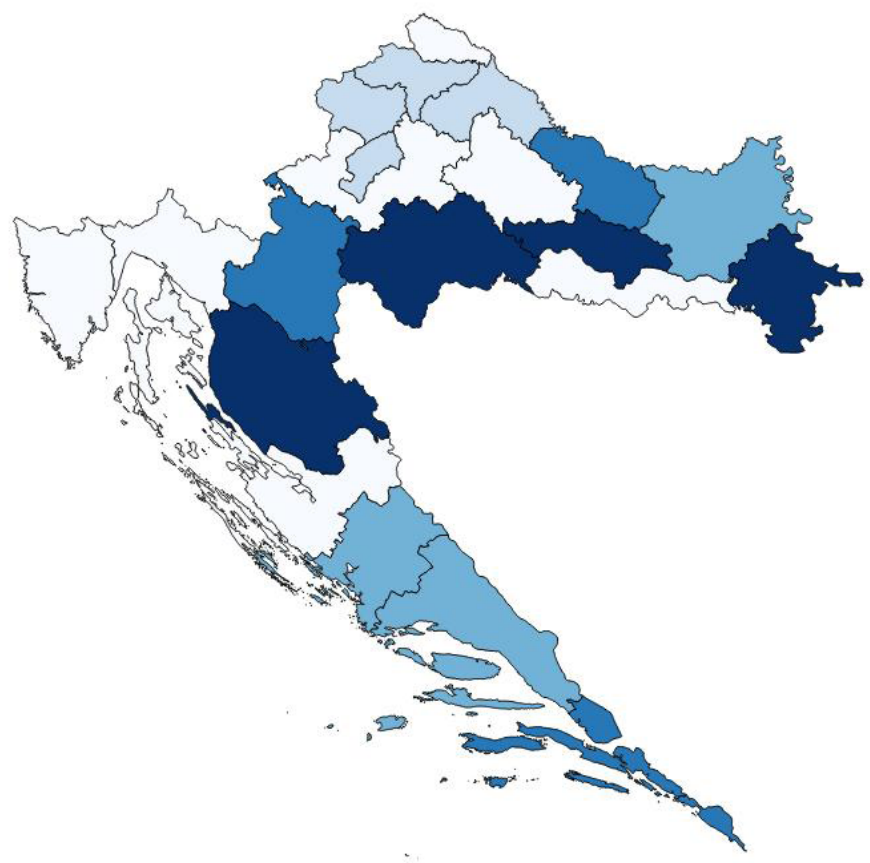

Source: Ministry of Administration Registry of NGOs, map @Sven Marcelić

the Association of Volunteer Veterans, the third largest federation of veteran NGOs, has member organizations in 8 of the 21 counties, with chapters and clubs like UDVDR. ${ }^{23}$

In addition to large associations of NGOs, there are 795 active NGOs that list veteran issues as their primary objective. ${ }^{24}$ Figure 1 shows their density across Croatia. Density is calculated as the number of NGOs divided by the number of inhabitants in the given county, with darker shades of blue representing higher density. ${ }^{25}$

23 Document available at http://www.uhbddr. hr/pdf/ustrojbeni\%20oblici\%20udruge. pdf. Accessed on February 25, 2018.

24 Information from Ministry of Administration, Official Registry of NGOs

25 I thank Sven Marcelić from the Department of Sociology at the University of Zadar for making the map.
Two findings stand out. Firstly, while active veteran NGOs cover practically the entire country, the highest density is in the parts of Croatian territory that was occupied during the war. However, when we disregard population size and look only at number of NGOs per county, the highest number of NGOs is in Zagreb (105), followed by Split County (103) and Osijek County with 76 NGOs. This suggests that many NGOs register in the largest cities, a finding supported by other research on NGO density in Croatia (Marcelić 2016). In the case of veteran NGOs, the motivation for setting up organizations in large cities is probably to focus on advocacy initiatives. Furthermore, these organizations' capacity to mobilize might be relying on a synergy with government and municipal authorities, which is what Bougarel (2006) describes in the case of Bosnia 
and Herzegovina. The fact that in 2017 the HDZ-led government secured mandatory financing of veterans' associations in the range of $0.3-1.0 \%$ of local government budgets (European Commission 2018) certainly speaks to that effect. All in all, veteran organizations seem to be important conduits in the clientelist relationship between veterans and the state (Stubbs and Zrinščak 2015).

The UDVDR was the first veteran organization to exert political pressure on the government, starting in 1993 when it adopted its first "Declaration on Veterans in the Homeland War", and 1994 when it adopted the "Resolution on Rights of Croatian Veterans of the Homeland War". Both documents were advocacy initiatives for regulating social rights of veterans and their families. In October 1996 UDVRD organized a high-profile event in the Zagreb Concert Hall, in the presence of high ranking government officials, at which the NGO president presented "15 Fundamental Demands", together with a petition signed by 90,000 veterans to support the introduction of these demands into the "Act on Rights of Croatian Veterans". ${ }^{26}$ Though the initial reaction of President Tuđman to these demands was unfriendly, two months later, in December, the government legislated a new "Act on the Rights of Croatian Veterans from the Homeland War and their Families" (NN 108/96, 23. December 1996). Following that, in 1997 the government set up a separate Ministry for Veterans, fulfilling another request by veteran organizations.

Overall, between 1993 and 1996, partly of its own volition, and party in response to pressures from veteran or-

26 Information based on the report on UDVRD website, http://www.udvdr.hr/ kategorija/aktivnosti-od-1992-1999. Accessed on February 25, 2018. ganizations, HDZ governments created a comprehensive institutional architecture of rights and entitlements for veterans and their families. This in turn created a strong bond between HDZ and the veteran population (Kasapović 1996), which has been described as a powerful client-patron axis charged both with symbolic meaning and material benefits (Čular 2000). According to Kasapović (2001), during the 1990s HDZ maintained rule by securing lavish state subsidies, privileged access to public sector jobs, privatization profits and diverse forms of social rights to veterans as one of its main interest groups. This echoes Ferrera's (1996) description of Italy's Christian Democrats (DC) as a mass patronage party which granted their clients job opportunities in the public sector and assisted them in obtaining benefits and subsidies from the state. This was implemented in part through the by-passing of regular state channels via the creation of special committees or other bodies entrusted with the provision of benefits (Ferrera 1996). The 1997 institution of a separate Ministry for Veterans in Croatia may have served similar purposes.

While HDZ governments extended both availability and reach of existing programmes to secure votes among their core constituency (Glaurdić and Vuković 2016), SDP-led governments attempted to regulate and cut down welfare programmes for veterans. Under the first SDP-led government 20012003, state pensions, disability support and other benefits were reduced and discontinued (Begić, Sanader and Žunec 2007). Conversely, significant changes regarding pensions occurred in election years when HDZ was incumbent. The first was an amendment to the Act on Pension Insurance in 1999, when a category of work disabled, which was until then receiving social transfers, were 
transferred to disability pensions. This created 37,112 new recipients of disability pensions (Bađun 2011). The number of disabled veterans registered in the pension system grew 3 times between 2003 and 2010, years of the first and second Sanader government. The largest increase was in election year 2007, with 5,500 new insurances issued for disability veterans. Similarly, in 2017 HDZ-led government reopened registration of disabled veterans into the pension system. As already mentioned, in the few months since the law was adopted, there were nearly 4,000 new applications.

Dolenec and Širinić (forthcoming) ${ }^{27}$ analysis of the impact of veterans' protest on electoral politics shows that in periods when HDZ is in opposition, veteran mobilization becomes highly contentious. In contrast, when HDZ is in government, veteran organizations align with the state, pro-actively mobilizing to strengthen its legitimacy and weaken oppositional claims to power. Furthermore, in a dynamic similar to the Law and Justice party (PiS) in Poland, HDZ supports and coordinates mass mobilization around key commemorative events of the Homeland War, through which the party renews its ties to veterans as "fathers of the state". Building on these findings in terms of demonstrating the mobilization capacity of veteran organizations, the following section focuses on how veteran organizations have used citizens' petitions for referenda as a tool for political mobilization.

\section{Veterans Mobilizing to Protect the Status Quo}

Citizens initiatives for referenda were introduced in Croatia with the constitutional amendments in November 2000,

27 Paper presented at the State Mobilized Contention international conference in Hong Kong, January 12-13, 2017. Currently submitted for publication. allowing citizens to initiate referenda upon the collection of signatures from $10 \%$ of voters in Croatia within 15 days. $^{28}$ Veterans' initiative "Headquarter for Defending the Dignity of the Homeland War" submitted a citizens' initiative to the parliament that same year, in April 2001. Feeling threatened by the change of government, veterans demanded a referendum be held to forbid Croatia's cooperation with The Hague Tribunal (Smerdel 2010). Two months earlier, in February 2001, warrants for the arrest of several people suspected of involvement in a wartime murder were issued, including the Croatian Army General Mirko Norac (Dolenec 2013). In response, the HDZ harnessed the revolt within the veterans' population to stage a large public protest in Split, ostensibly in his honour. According to some analysts, at that moment HDZ had hoped to topple the SDP-led coalition (Babić 2003). This was the context for the April 2001 veterans' initiative against cooperation with The Hague Tribunal. Though the initiative collected 400,000 signatures (Smerdel 2010), the referendum never took place. The legal reason that was used to render this initiative invalid was the fact that the Referendum Act had not yet been amended, and hence the legal framework was not in conformity with constitutional changes.

Veteran organizations initiated their second petition for referendum in 2007, again with the objective of stopping Croatia's cooperation with The Hague Tribunal. However, the political opportunity structure was quite different. The SDP-led coalition had been replaced by a re-vamped HDZ under the leadership

28 By comparison, in Switzerland the required percentage of signatures is less than $2 \%$ of registered voters, while the period for the collection of signatures is 18 months (Kriesi 2005). Closer to home, in Slovenia around $2 \%$ of voters' signatures must be collected in 35 days (Erceg 2011). 
of Ivo Sanader. He had initiated the transformation of a nationalist organisation into a Christian Democratic Party (Zakošek 2002; Dolenec 2008, 2009). In other words, the referendum initiative took place in a context in which HDZ stood behind European integration as the primary political objective, though not without cost to its constituency (Čular 2010). Without HDZ support veterans were not able to collect the necessary number of signatures, though a respectable number of $296,000^{29}$ testifies to the serious rift that the party's stance towards The Hague Tribunal had caused in its voter base.

After the 2007 initiative, the veteran population retreated from large public campaigns, to return after an SDP-government came into office in December 2011. With HDZ again in opposition, veterans' associations became politically active. In March 2013 the "Headquarter for the Defense of Croatian Vukovar" campaigned in the local election against the incumbent Social Democratic mayor, supporting the HDZ candidate in exchange for his endorsement of their demand to grant Vukovar the status of "special piety" which would exempt it from the use of Serbian Cyrillic on public buildings. Their candidate did not win the local election, and the government pursued the implementation of the said policy in autumn the same year. This action was met with acts of civil disobedience, including repeatedly tearing down Serbian Cyrillic placards - leading to several arrests between September and November of 2013. ${ }^{30}$

29 "296,000 moral acts", published on Oct 18, 2007 by Hrvatsko kulturno vijeće, available at: http://www.hkv.hr/izdvojeno/komentari/mmb/1445-komentar-296-tisua-moralnih-inova.html. Accessed March 18, 2018.

30 On September 23, 2013 N1 television reported on six arrests in Vukovar, available at: http://hr.nlinfo.com/a1319/Vijesti/ U-Vukovaru-porazbijali-i-poskidali-sve-dvo-
The standoff between veteran organizations and the SDP-led government culminated during Remembrance Day on November 18, 2013, when the procession through the streets of Vukovar with the Prime Minister, the President of the State, other government officials and diplomats, was cordoned off into a different route from the one led by war veterans' associations ${ }^{31}$. Building on a month-long crisis in which veterans were tearing down placards from public buildings in Vukovar, the situation was close to violence.

The day before, on November 17, the Headquarter had started the collection of signatures for a referendum in which they proposed to restrict the use of Serbian Cyrillic on public buildings to locations where the Serb population was the majority, invalidating their language right as a constitutionally recognised $\mathrm{mi}$ nority. Undertaking a public campaign for which they had HDZ's tacit support, they managed to collect 632,165 signatures. ${ }^{32}$ which was more than enough for initiating a referendum. Like was the case in 2001 and 2007, the Constitutional court ruled the question inadmissible, and the referendum did not take place. However, veteran organizations soon "upped the odds" of their confrontation with the SDP government. In October 2014, they occupied a public square in front of the Ministry of Veterans on 66 Savska street, one of the busiest thor-

jezicne-ploce-pet-osoba-je-uhiceno.html. Accessed March 18, 2018.

31 How the event unfolded can be seen in the report by TV station Slavonska Televizija, broadcast on Nov 18, 2013. The news clip is available at https://www.youtube.com/ watch?v=plDk9XqaHGQ. Accessed March 18, 2018.

32 "Stožer uz pjesmu predao potpise za referendum o ćirilici", December 16, 2013, Večernji list; available at: https://www. vecernji.hr/vijesti/stozer-632165-potpisaza-referendum-o-cirilici-nosi-u-sabor909338. Accessed March 18, 2018. 
oughfares in Zagreb, demanding the resignation of the Minister and his key aids. Through this action they initiated a sit-in that lasted 555 days $^{33}$, ending after HDZ returned to power. The start of this protest was aligned with the electoral campaign for presidential elections, which the incumbent Social Democratic president Ivo Josipović lost to HDZ candidate, Kolinda Grabar-Kitarović. The first place she visited on election night, and again upon assuming office, was the veterans' tent on 66 Savska Street. Though the 2015 parliamentary election was close, ${ }^{34} \mathrm{HDZ}$ won that too. HDZ party member who had been an active participant in the veteran protest on 66 Savska Street became the new Minister of Veterans.

\section{Croatia as a Conservative Welfare Regime}

The objective of this paper was to theorize about the type of welfare state that emerged in Croatia post-1990, focusing specifically on ways in which the evolution of welfare programmes for veterans, and the gradual strengthening of veteran organizations as pivotal political actors, impacted its morphology. Having in mind that comparative research on Croatia as a welfare regime type, as well as many aspects of the character and impact of state programmes for veterans in Croatia are under-researched, a more comprehensive treatment of many substantive issues raised in this

33 "Nakon 555 dana napokon završio braniteljski prosvjed u Savskoj", April 26, 2016, Večernji list; available at: https://www. vecernji.hr/vijesti/nakon-555-dana-konacno-je-zavrsio-braniteljski-prosvjed-usavskoj-1079361. Accessed March 18, 2018.

${ }^{34}$ The Homeland Coalition, led by HDZ, won $33,4 \%$ of the vote in comparison with the coalition led by the Social Democrats, which won $33,2 \%$ of the vote (State Electoral Commission, data available on their website: www.izbori.hr). paper must await further analyses. This analysis should be read primarily as theory development, fostering new hypotheses about the role of veteran organizations and state programmes for veterans in the development of the welfare state regime in Croatia.

In Croatia, apart from pensioners, the largest social group compensated by the state are war veterans. Croatia currently has a population of around 500,000 registered veterans, which in the mid1990 started organizing into large federative organizations across the territory of Croatia. Partly in response to this mobilization, from 1994 onwards HDZ governments created a comprehensive institutional architecture of entitlements for veterans, instituting durable material linkages alongside symbolic ties to this population. Over time, the dense organizational structure of veteran organizations and their synergy with governmental and municipal authorities contributed to their strong mobilizational capacity, influencing the country's political dynamics - usually to strengthen HDZ electorally and to weaken oppositional claims to power.

However, this relationship has on occasion created significant pressure on HDZ governments as well. Clients with strong mobilization capacity are only ever partially in service of their patron. Maintaining their power depends on occasionally demonstrating that they can "go rogue" on their political ally, by vetoing decisions or putting pressure on governments that drift away from their preferred policy direction. This dynamic was revealed in how veteran organizations have used citizens' petitions for referenda. Out of the three instances when they mobilized to collect signatures for referenda, twice they had HDZ support, and once they were in opposition to official HDZ policy. The varied success of these initiatives testi- 
fies to the importance that alliance with HDZ has for the veteran organizations: only when they worked together were they able to cross the high mobilization necessary to fulfil criteria for initiating a referendum. Tying the strands of this analysis together, it seems safe to say that veteran organizations are a crucial interest group shaping Croatia's political dynamics. This is reflected both in the domain of the welfare state, where they have often been able to veto major changes that go against their interests, and in the domain of electoral politics, where they have engaged in contentious politics with the intention of influencing electoral outcomes to the advantage of the party they perceive as protecting their interests.

How does the prominence of veterans as the pivotal political actor factor into our analysis of Croatia as a conservative welfare regime? A strong reliance on the family for a broad range of care work is the central feature Croatia shares with other conservative welfare regimes. Furthermore, the clientelist character of state-society relations links it specifically to the Southern variant of conservative welfare regimes. Finally, and distinctly, the fact that the state sustains a very large population of men on social benefits creates complex political and social effects, only some of which have been addressed in this paper. On the one hand, veterans have emerged as a political actor capable of influencing elections, reinforcing dominant cleavages and hence sustaining the militarized political culture that permeates political life in Croatia. On the other hand, it has also lead to a situation in which the fundamental principle of deservedness from work, which underlies the concept of solidarity in welfare states, is in Croatia in competition with the prin- ciple of deservedness derived from the "moral asymmetry" whereby the state compensates veterans for their absolute sacrifice in the past. This "compensatory" character of state-society relations, which is characteristic of family policy in Croatia generally, creates contradictory impulses of dependency on the state and resentment towards the state. Even though veterans are celebrated as heroes, the fact that they resemble recipients of care rather than the model of the male breadwinner, might be having complex effects on patriarchal gender relations. Notwithstanding that, the key distinction between veterans on the one hand, and women and children on the other vis-à-vis the state, is the strong mobilization capacity of the former. Following Schneider and Ingram's (1993) argumentation, they represent an advantaged group which is amply compensated by the state, while policies directed towards children and mothers, who are socially construed as "dependents", usually amount to lip-service: verbal displays of concern that are not followed by adequate allocation of resources. At the same time, if social programmes for veterans support entire families, perhaps they should be thought of as part of family policy, impacting both gender relations and electoral dynamics. In summary, though many features of this analysis are exploratory rather than confirmatory, Croatia seems to be a specific clientelist variant of a conservative welfare regime, sustained by veteran mobilizations, but at the same time eroded by the dependency, resentment and a myriad of other social impacts that these programmes have on the target population. Future research on the welfare state in Croatia will hopefully address them, putting to the test some of the arguments that this paper has brought forward. 


\section{References}

Aidukaite, Jolanta. 2009. Old welfare state theories and new welfare regimes in Eastern Europe: Challenges and implications. Communist and Post-Communist Studies. (42) 1: 23-39.

Ainsworth, Scott. 1995. Electoral Strength and the Emergence of Group Influence in the Late 1800s The Grand Army of the Republic. American Politics Quarterly. (23) 3: 319-338.

Babić, Jasna. 2003. Hrvatska napokon smogla snage da osudi svoje ratne zločince. Nacional, March 26, 2003. Available online at: http://www.nacional.hr/clanak/10546/hrvatska-napokon-smogla-snage-da-osudi-svoje-ratnezlocince

Bađun, Marijana. 2009. Korisnici mirovina koji su pravo na mirovinu ostvarili pod povoljnijim uvjetima. Newsletter of the Institute for Public Finance. Zagreb, No. 44, August, 2009.

Bađun, Marijana. 2011. Why are there so many disability pensions beneficiaries in Croatia? Newsletter of the Institute for Public Finance. Zagreb, No. 56, May, 2011.

Begić, Nada, Sanader, Mirjana, Žunec, Ozren. 2007. Ratni veterani u Starom Rimu i u današnjoj Hrvatskoj. Polemos. (10) 20: 11-30.

Bendix, Reinhard. 1964. National-building and citizenship. Oakland. University of California Press.

Berdak, Oliwia. 2015. Reintegrating veterans in Bosnia and Herzegovina and Croatia: Citizenship and gender effects. Women's Studies International Forum. (49) 48-56.

Berman, Sheri. 2006. The Primacy of Politics: Social Democracy and the Making of Europe's Twentieth Century. Princeton: Princeton University Press.

Bougarel, Xavier. 2006. The shadow of heroes: former combatants in postwar
Bosnia-Herzegovina. International Social Science Journal. (58) 189: 479490.

Brooks, Clem, Manza, Jeff. 2007. Why Welfare States Persist: The Importance of Public Opinion in Democracies. Chicago: University of Chicago Press.

Čular, Goran. 2000. Political Development in Croatia 1990-2000. Politička misao. (37) 5: 30-46.

Čular, Goran. 2010. Treba li suvremenim strankama članstvo? Političke analize. (1) 3: 20-24.

Deacon, Bob. 2000. Eastern European welfare states: the impact of the politics of globalization. Journal of European Social Policy. (10) 2: 146-161.

Dobrotić, Ivana. 2008. Sustav skrbi za branitelje iz Domovinskog rata. Revija za socijalnu politiku. (15) 1: 57-83.

Dobrotić, Ivana. 2015. Politike usklađivanja obiteljskih obaveza i plaćenog rada i položaj roditelja na tržištu rada. Revija za socijalnu politiku. (22) 3: 353-374.

Dobrotić, Ivana, Vučković, Tanja. 2016. Who Should Finance Childcare? Multilevel Analysis of 24 Countries. Revija za socijalnu politiku. (23) 3: 323-357.

Dolenec, Danijela. 2008. Europeanization as a Democratising Force in Postcommunist Europe: Croatia in Comparative Perspective. Croatian Political Science Review. (45) 5: 23-46.

Dolenec, Danijela. 2009. Demokratizacija stranačkog sustava u Hrvatskoj: ponuda i potražnja javnih politika. In: Petak, Zdravko. (ed.). Stranke i javne politike. Izbori u Hrvatskoj 2007. Zagreb: Fakultet političkih znanosti.

Dolenec, Danijela. 2013. Democratic Institutions and Authoritarian rule in Southeast Europe. Colchester: ECPR Press. 
Dolenec, Danijela. 2014. Zašto SDPova vlada nije socijaldemokratska? Političke analize. (5) 20: 33-38.

Dolenec, Danijela, Širinić, Daniela. (forthcoming). Party-led Mobilization: Veterans as a Pivotal Political Actor. Unpublished.

Emmeneger, Patrick, Kvist, Jon, Marx, Paul and Petersen, Klaus. 2015. Three Worlds of Welfare Capitalism: The making of a classic. Journal of European Social Policy. (25) 1:3-13.

Esping Andersen, Gosta. 1990. The three worlds of welfare capitalism. New Jersey: Princeton University Press.

Esping Andersen, Gosta. 2000. Social Foundations of Postindustrial Economies. Oxford. Oxford University Press.

Esping Andersen, Gosta. 2015. Welfare regimes and social stratification. Journal of Europeaen Social Policy. (25) 1: 124-134.

Erceg, Marija. 2011. Referendumska demokracija u Sloveniji. Političke analize. (2) 6: 59-61.

European Commission. 2018. Country Report Croatia 2018. Including an InDepth Review on the prevention and correction of macroeconomic imbalance. $\{\mathrm{COM}(2018) 120$ final $\}$. Reform available on the website of the European Commission.

Eurostat 2017. Government expenditure on social protection. Available from: http://ec.europa.eu/eurostat/statistics-explained/index.php/Government_expenditure-on_social_protection. Accessed February 25, 2018.

Ferenčak, Nataša, Kardov, Kruno, Rodik, Petra. 2003. Booklet on war veterans' entitlements and welfare systems. Unpublished.

Ferrera, Maurizio. 1996. The "Southern Model" of Welfare in Social Europe. Journal of European Social Policy. (6) 1: 17-37.
Ferge, Zsuzsa. 1997. The Changed Welfare Paradigm: The Individualization of The Social. Social Policy \& Administration. (31) 1: 20-44.

Gal, John, Bar, Michael. 2000. The needed and the needy: The policy legacies of benefits for disabled war veterans in Israel. Journal of Social Policy. (29) 4: 577-598.

Gellner, Ernest, Breuilly, John. 2008. Nations and nationalism. Ithaca: Cornell University Press.

Gerber, David A. 2003. Disabled veterans, the state, and the experience of disability in Western societies, 19141950. Journal of social history. (36) 4 : 899-916.

Glaurdić, Josip, Vuković, Vuk. 2016. Voting after war: Legacy of conflict and the economy as determinants of electoral support in Croatia. Electoral Studies. (42): 135-145.

Greskovits, Béla. 1996. The Political Economy of Protest and Patience: East European and Latin American Transformations Compared. Budapest: CEU Press.

Häusermann, Silja, Picot, Georg, Geering, Dominik. 2013. Rethinking Party Politics and the Welfare State - Recent Advances in the Literature. British Journal of Political Science. (43) 1: 221-240.

Hronesova, Jessie. 2016. Might Makes Right: War-Related Payments in Bosnia and Herzegovina. Journal of Intervention and Statebuilding. (10) 3 : 339-360.

Jović, Dejan. 2017. Rat i mit. Politika identiteta u suvremenoj Hrvatskoj, Zagreb: Fraktura.

Kasapović, Mirjana. 1996. Demokratska tranzicija $i$ političke stranke. Zagreb: Fakultet političkih znanosti.

Kasapović, Mirjana. 2001. Demokratska konsolidacija i izborna politika u Hrvatskoj. In: Kasapović, Mirjana. (ed.). 
Hrvatska politika 1990-2000. Zagreb, Fakultet političkih znanosti.

Keman, Hans. 2017. Social Democracy: A Comparative Account of the LeftWing Party Family. London and New York: Routledge.

Korpi, Walter. 1983. The Democratic Class Struggle. London: Routledge \& K. Paul.

Kriesi, Hanspeter. 2005. Direct Democratic Choice: The Swiss Experience. Lenham: Lexington Books.

Leitner, Sigrid. 2003. Varieties of Familialism. The caring function of the family in comparative perspective. European Societies. (5) 4: 353-375.

Lendvai, Noémi, Stubbs, Paul. 2015. Europeanization, Welfare and Variegated Austerity Capitalisms - Hungary and Croatia. Social Policy \& Administration. (49) 4: 445-465.

Maddaloni, Domenico. 2014. The Warfare-Welfare Nexus. An Ecological-Evolutionary Conceptual Framework for the Analysis of the Rise and Decline of National Public Welfare Systems. (No. 132). CELPE-Centre of Labour Economics and Economic Policy, University of Salerno, Italy.

Mahečić, Zvonimir. 2003. Izazovi reforme i smanjenja oružanih snaga Republike Hrvatske: Politika personalnog upravljanja kao posljedica ratnih zbivanja i izgradnje oružanih snaga Republike Hrvatske. Polemos. (6) 1112: 49-69.

Marcelić, Sven. 2016. Density of NGOs in Croatia: some economic and demographic factors. Presented at the Policy Analysis and Investigative Journalism Workshop, October 19, 2016, Zagreb.

Marijan, Davor. 2008. Sudionici i osnovne značajke rata u Hrvatskoj 1990.1991. Časopis za suvremenu povijest. (40) 1: 47-63.

Matković, Teo, Dobrotić, Ivana. 2013. Promjene $\mathrm{u}$ obuhvatu programima predškolskog odgoja i obrazovanja u Hrvatskoj na nacionalnoj i županijskoj razini između 1990. i 2012. godine. Revija za socijalnu politiku. (20) 1: 65-73.

Mihalec, Ivica, Pavlin, Pamela, Relja, Marin. 2012. Utjecaj društvenih skupina na kreiranje javnih politika u Hrvatskoj. Student paper, unpublished.

Milanović, Branko. 1998. Income, Inequality, and Povertyduring the Transitionfrom Planned to Market Economy. World Bank. Available at: http:// documents.worldbank.org/curated/ en/229251468767984676/Income-inequality-and-poverty-during-the-transition-from-planned-to-market-economy.

Obradović, Nikolina. 2017. War Veteran's Policy in Bosnia and Herzegovina. Revija za socijalnu politiku. (24) 1: 93-106.

Orenstein, Mitchell A. 2008. Poverty, Inequality and Democracy: Postcommunist Welfare States. Journal of Democracy. (19) 4: 80-94.

Orenstein, Mitchell A., Haas, Martine R. 2005. Globalization and the Development of Welfare States in Postcommunist Europe. In: Glatzer, Miguel, Rueschemeyer, Dietrich. (eds.) Globalization and the Future of the Welfare State. Pittsburgh: University of Pittsburgh Press.

Pateman, Carole. 1988. The patriarchal welfare state. In: Gutman, Amy. (ed.). Democracy and the Welfare State. Princeton: Princeton University Press.

Pierson, Paul. 2004. Politics in Time: History, Institutions, and Social Analysis. Princeton: Princeton University Press.

Schneider, Anna, Ingram, Helen. 1993. Social Construction of Target Populations: Implications for Politics and Policy. American Political Science Review. 87 (2): 334-347. 
Skocpol, Theda. 1995. Protecting soldiers and mothers. The Political Origins of Social Policy in United States. Boston: Harvard University Press.

Smerić, Tomislav. 2009. Uz temu: "Hrvatska vojska - hrvatsko društvo". Društvena istraživanja. (18) 3: 337-337.

Smerdel, Branko. 2010. Neposredno odlučivanje i njegove ustavne granice. Hrvatska pravna revija. (10) 11: 1-9.

Stubbs, Paul, Zrinščak, Siniša. 2009. Croatian social policy: The legacies of war, state-building and late Europeanisation. Social Policy and Administration. (43) 2: 121-135.

Stubbs, Paul, Zrinščak, Siniša. 2011. Rethinking clientelism, governance and citizenship in social welfare: The case of Croatia. Lecture held at ESPANet Annual Conference, 8-10 September 2011.

Stubbs, Paul, Zrinščak, Siniša. 2015. Citizenship and Social Welfare in Croatia: Clientelism and the Limits of ' $\mathrm{Eu}$ ropeanisation. European Politics and Society. (16) 3: 395-410.

Thomson, Stuart. 2000. The Social Democratic Dilemma: Ideology, Governance and Globalization. London: Macmillan Press.

Williamson, Vanessa, Skocpol, Theda, Coggin, John. 2011. The Tea Party and the remaking of Republican conservatism. Perspectives on Politics. (9) 1: 25-43.
Wolin, Sheldon S. 1987. Theorizing the Welfare State. Political Theory. (15) 4: 467-500.

World Bank. 2001. Croatia: Economic Vulnerability and Welfare Study. Available from http://documents.worldbank. org/curated/en/709081468770636975/ Croatia-Economic-vulnerability-andwelfare-study. Accessed February 25, 2018.

World Bank. 2010. Croatia: Social Impact of the Crisis and Building Resilience, Available from https:// openknowledge.worldbank.org/handle/10986/2903. Accessed February 25, 2018.

Zakošek, Nenad. 2002. Politički sustav Hrvatske. Zagreb: Fakultet političkih znanosti.

Zrinščak, Siniša. 2008. Obiteljska politika Hrvatske. In Puljiz, Vlado. (ed.). Socijalna politika Hrvatske. Zagreb: Pravni fakultet u Zagrebu.

Žunec, Ozren. 1998. Rat u Hrvatskoj 1991.-1995. Prvi dio: Uzroci rata i operacije do Sarajevskog primirja.' Polemos. (1) 1: 57-87.

Žunec, Ozren. 1998. Rat u Hrvatskoj 1991.-1995. Drugi dio: Od Sarajevskog primirja do završnih operacija. Polemos. (1) 2: 111-136.

Žunec, Ozren. 2006. Apsolutna žrtva i relativna kompenzacija: proturječja društvenog položaja veterana i državne skrbi za ratne veterane i invalide. Polemos. (9) 18: 11-42. 


\section{Vojnička država? Veterani i socijalna država u Hrvatskoj}

Sažetak Rad se bavi inačicom socijalne države koja se od devedesetih godina razvijala u Hrvatskoj, odnosno pitanjem kako su socijalni programi za veterane i pretvaranje veteranskih organizacija u ključne političke aktere utjecali na njezin razvoj. Hrvatska ima oko pola milijuna registriranih veterana te snažne i brojne veteranske organizacije. Djelomice reagirajući na mobilizaciju veteranskih organizacija, vlade predvođene HDZ-om stvarale su od 1994. trajne materijalne povlastice za veterane, uz simbolične poveznice koje njeguju od svršetka Domovinskog rata. Jačanje veteranskih organizacija kao političkih aktera utjecalo je stoga na razvoj socijalne države u Hrvatskoj. Snažno oslanjanje na obitelj u pružanju skrbi središnje je obilježje koje Hrvatska dijeli s drugima konzervativnim socijalnim državama, dok je klijentelistički karakter odnosa između države i društvenih skupina povezuje s južnim tipom konzervativne socijalne države. Nadalje, Hrvatsku obilježavaju "kompenzacijski" socijalni programi, kako za veterane tako i u obiteljskoj politici općenito, koji imaju kontradiktorne društvene učinke. Klijentelističku inačicu konzervativne socijalne države u Hrvatskoj održava politička mobilizacija veteranskih organizacija, ali je istodobno nagrizaju odnosi ovisnosti, predbacivanja i brojni drugi socijalni učinci tih programa. Ovaj rad ukazuje na potrebu obuhvatnijih komparativnih istraživanja socijalne države u Hrvatskoj.

Ključne riječi tipovi socijalne države, Esping Andersen, veterani, politička mobilizacija, Hrvatska 
